IP Periodica Polytechnica Civil Engineering

60(2), pp. 135 1432016

DOI: $10.3311 /$ PPci.7917

Creative Commons Attribution (1)

RESEARCH ARTICLE

\section{Shear Strength Behaviour of Clay Reinforced with Treated Coir Fibres}

\author{
Vishwas N. Khatri, Rakesh K. Dutta, Gayathri Venkataraman, Rajnish Shrivastava
}

Received 16-01-2015, revised 11-04-2015, accepted 24-04-2015

\begin{abstract}
The effect of treated coir fibres on the shear strength behaviour of clay is presented in this study. A series of consolidated undrained test were performed on soil reinforced with untreated, sodium hydroxide treated and carbon tetrachloride treated fibres. The coir fibre content was varied from $0.4 \%$ to $1.6 \%$. The results indicated that the deviator stress at failure of the clay and clay with untreated coir fibres can be increased by treatment with carbon tetrachloride and sodium hydroxide. A significant increase was also observed in shear strength parameters of clay reinforced with coir fibres at different percentages. The two parameter dependent hyperbolic models were used for predicting the experimental results. The back predicted stressstrain curve at different fibre percentage was found to compare well with the experimental results. The clay reinforced with untreated/treated coir fibres has shown improved strength behaviour, it can be used for short term stability problems.
\end{abstract}

\section{Keywords \\ Coir fibres · Treatment $\cdot$ Deviator stress $\cdot$ Cohesion $\cdot$ Friction}

\section{Vishwas N. Khatri}

Department of Civil Engineering, National Institute of Technology, Hamirpur 177005, Himachal Pradesh, India

\section{Rakesh K. Dutta}

Department of Civil Engineering, National Institute of Technology, Hamirpur 177005, Himachal Pradesh, India

e-mail: rakeshkdutta@yahoo.com

\section{Gayathri Venkataraman}

Department of Civil Engineering, Sri Krishna College of Engineering and Technology, Coimbatore, Tamilnadu, India

e-mail: gayathriiitdelhi@gmail.com

\section{Rajnish Shrivastava}

National Institute of Technology, Hamirpur - 177005, Himachal Pradesh, India e-mail: rajnishshri@gmail.com

\section{Introduction}

The reinforced soil concept is essentially based in the mobilization of inter facial shearing resistance between the soil and reinforcement which in turn restrains the lateral deformation of the soil. For this purpose, a variety of materials are being used as reinforcing materials such as metallic elements and/or geosynthetics [1]. Further, in India, the production of coir fibres from the husk of the coconut is the largest and about 13000 million nuts are annually harvested. Out of the total production of nuts annually, less than $25 \%$ are used industrially. The remaining husk obtained from the nuts either becomes garbage or are dried and burnt as fuel in India [1]. This destruction of a potentially useful material is due to lack of alternate uses of coir fibres. On the other hand, civil engineers around the world are constantly in search of alternate materials which are required for cost effective solutions particularly in developing nations. In this regard, the coir fibres may offer a variety of soil reinforcement applications. This paper presents the results of the effect of treated coir fibres on the shear strength behaviour of the clay for application in short-term stability-related problems.

\section{Background}

Coir is a biodegradable organic fibrous material containing $40 \%$ lignin and $54 \%$ cellulose [2]. Coir is useful in different applications as reinforcing material in soil due its high lignin content [5]. Many researchers [1- -10$]$ have shown that coir fibre reinforcement can significantly improve the engineering properties of soil. But the presence of the pectins, lignin, hemicellulose, silica and pith on the surface of these fibres results in poor interaction with the soil [3]. Significant increase in strength parameters and stiffness of sand reinforced with coir fibres was reported by [2]. The dimensional and mechanical properties of coir fibres as a function of fibre length were investigated by [4]. The behaviour of sand reinforced with coir fibres and Geotextiles was similar to that observed with synthetic fibres and meshes [1]. The strength and stiffness of tropical soil were increased with the inclusion of discrete coir fibres of about $1-2 \%$ by weight [5]. The coir fibres have good strength and resistance to bio-degradation over a long period of time [6]. The uncon- 
fined compressive strength of black cotton soil reinforced with bitumen coated coir fibres shows marginal variation in strength as compared to uncoated coir fibres [7]. Numerical simulation of triaxial tests on coir fibre reinforced clay was conducted by [8]. The results of the tests and the model were quite comparable. The unconfined compressive strength test and unconsolidated undrained triaxial test on low compressible clay reinforced with coir fibres were reported by [9]. The results of the unconfined compressive strength test with the addition of $30 \mathrm{~mm}$ and $15 \mathrm{~mm}$ long coir fibres to the clay indicated a decrease and an increase in its unconfined compressive strength, respectively. It was further mentioned in this study that length of fibre is a significant factor that influences the strength of fiber-reinforced soils. The effect of treated coir fibres on the unconfined compressive strength of clay was conducted by [10]. However, hardly any literature is available to study the effect of treated coir fibres on the shear strength behaviour of clay. In the present work, the effect of treated fibres on the shear strength behaviour of locally available clay is studied. The coir fibres used for reinforcing the clay are (i) untreated (ii) treated prior to use with $\mathrm{NaOH}$ (iii) treated prior to use with $\mathrm{CCl}_{4}$. The stress-strain response in various cases are plotted, compared and discussed for possible use to solve short-term stability-related problems.

\section{Materials used and Experimental Procedure}

The clay used in this study was collected from a place near Hamirpur $\left(31.63^{\circ} \mathrm{N}, 76.52^{\circ} \mathrm{E}\right)$, Himachal Pradesh, India. The clay had a specific gravity of 2.67 , a liquid limit of $23.1 \%$ and a plastic limit of $11.1 \%$. The maximum dry unit weight and optimum moisture content were $18.6 \mathrm{kN} / \mathrm{m}^{3}$ and $12 \%$, respectively, and were determined as per [11]. It was classified as clay of low compressibility as per Unified Soil Classification System. The coir fibres were obtained from the coir rope made of brown coir and is shown in Fig. 1. (1).

Tab. 1. Properties of coir fibres

\begin{tabular}{cc}
\hline Property & Coir fibres \\
\hline Specific gravity & 1.2 \\
Load at failure $(\mathrm{kN})$ & 0.20 \\
Strain at failure $(\%)$ & 42 \\
Thickness $(\mathrm{mm})$ & 0.13 \\
\hline
\end{tabular}

Tab. 2. Concentration and composition of chemical used for treatment of coir fibres

\begin{tabular}{cc}
\hline Carbon tetra chloride & Sodium hydroxide \\
\hline Assay $(\mathrm{GLC})=99 \%$ & Carbonate $2 \%$ \\
Wt. per $\mathrm{ml}$ at $20^{\circ} \mathrm{C}=1.590 \mathrm{gm}$ & Chloride $0.01 \%$ \\
Boiling range $(95 \%)=76-77^{\circ} \mathrm{C}$ & Sulphate $0.05 \%$ \\
N.V.M. $-0.003 \%$ max. & Potassium $0.1 \%$ \\
& Silicate $0.05 \%$ \\
& Zinc $0.02 \%$ \\
& $\mathrm{~N} / 10$ solution
\end{tabular}

The yarns of the coir ropes were separated and the fibres were cut in the length of $15 \mathrm{~mm}$ (Fig. 1.b)) and the fibres were separated (Fig. 1(c)) and separated fibres are shown in Fig.11.d). The properties of these coir fibres are shown in Table 1. The coir fibres obtained as shown in Fig. 1](d) was treated with sodium hydroxide solution and $\mathrm{CCl}_{4}$ solution for 24 hours. The chemical treatment of coir fibres was carried out according to the procedure reported by [12]. Thus, coir fibres were dipped in chemical for one minute in order to study the effect of chemical on the water absorption. Whereas, in the present study, the coir fibres used were longer dipped ( 24 hours) in $\mathrm{NaOH}$ and $\mathrm{CCl}_{4}$ in order to remove impurities on the surface of coir fibres. After 24 hours, the fibres were removed from the beaker and allowed to dry at room temperature $\left(27^{0} \pm 2^{0}\right)$ for a week. This is required for the conditioning of coir fibres before use. The concentration and composition of chemicals used for the treatment of coir fibres are given in Table 2. The SEM image of untreated coir fibres and $\mathrm{NaOH}$ and $\mathrm{CCl}_{4}$ treated coir fibres reported by [10] reveals that pectins and other impurities are present on the surface of untreated coir fibres which get removed and pits and surface irregularities become quite visible when untreated fibres were treated with $\mathrm{NaOH}$ and $\mathrm{CCl}_{4}$. It was further reported in [10] that the formation of pits and clarity of surface irregularities is better for the $\mathrm{CCl}_{4}$ treated coir fibres as compared to $\mathrm{NaOH}$ treated coir fibres. The cause for this is attributed to better surface cleaning properties of $\mathrm{CCl} 4$ as compared to $\mathrm{NaOH}$. A series of consolidated undrained tests were conducted on the pure clay and clay reinforced with the untreated/treated coir fibres at varying contents. All the specimens were prepared corresponding to optimum moisture content and dry unit weight. The dry unit weight and optimum moisture content of unreinforced as well as reinforced clay samples were performed using a standard proctor test. The corresponding values of dry unit weight and optimum moisture content are shown in Table 3 . The consolidated undrained test on samples was carried out in accordance with [14]. The soil samples for triaxial tests were prepared using a metallic mould of $38 \mathrm{~mm}$ inner diameter $\times 76 \mathrm{~mm}$ length with detachable collars. For reinforced soil specimens, the fibres were added as a percentage of the dry weight of the clay.

The specimens were made with fiber contents of $0.4 \%, 0.8 \%$ and $1.6 \%$. All the specimens were saturated by dipping the specimen for 72 hours prior to taking the test. After 72 hours it was assumed that the specimen was saturated. Accordingly, the B parameter calculated was 0.96. During the consolidation stage with cell pressure held constant the drainage valve of triaxial test was kept open and the consolidation of the sample was allowed. The complete consolidation was assumed to happen once the water level in the burette which is connected to the drainage valve becomes constant. Thereafter the drainage valve was closed and the deviator stress was applied to a sample under undrained condition. The strain rate was set at $1.5 \mathrm{~mm} / \mathrm{min}$. The cell pressure during each test was kept as $78.48 \mathrm{kPa}, 156.96 \mathrm{kPa}$ and $313.92 \mathrm{kPa}$ respectively. The test was conducted up to the strain of about $20 \%$, unless the failure occurs earlier. The pore 


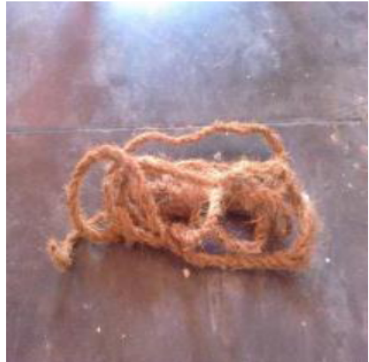

(a)

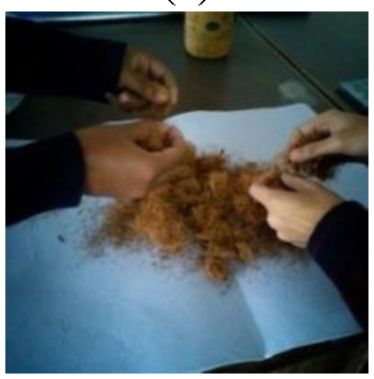

(c)

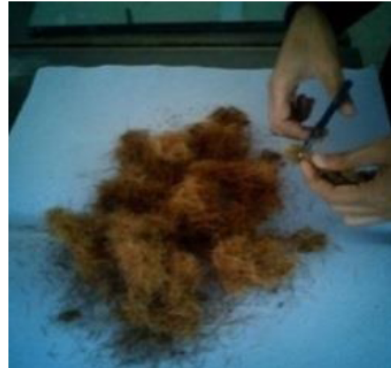

(b)

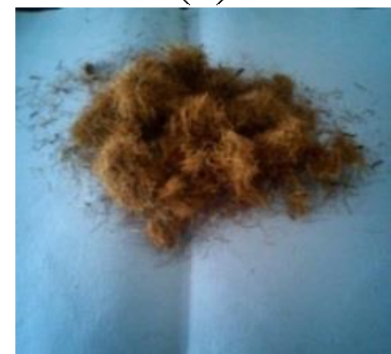

(d)

Fig. 1. Coir (a) rope (b) fibre cutting $15 \mathrm{~mm}$ in length (c) separation of fibres (d) separated fibres

Tab. 3. The dry unit weight and optimum moisture content of unreinforced and reinforced clay (after [13]).

\begin{tabular}{ccccccc}
\hline Coir Fibre (\%) & \multicolumn{2}{c}{ Soil with untreated fibres } & \multicolumn{2}{c}{ Soil with $\mathrm{NaOH}$ treated fibres } & \multicolumn{2}{c}{ Soil with $\mathrm{CCl}_{4}$ treated fibres } \\
\cline { 2 - 7 } & OMC (\%) & $\begin{array}{c}\text { MDD } \\
\left(\mathrm{kN} / \mathrm{m}^{3}\right)\end{array}$ & OMC $(\%)$ & $\begin{array}{c}\text { MDD } \\
\left(\mathrm{kN} / \mathrm{m}^{3}\right)\end{array}$ & OMC $(\%)$ & $\begin{array}{c}\text { MDD } \\
\left(\mathrm{kN} / \mathrm{m}^{3}\right)\end{array}$ \\
\hline 0.4 & 12.60 & 18.23 & 12.30 & 18.34 & 12.28 & 18.40 \\
\hline 0.8 & 12.90 & 18.16 & 12.70 & 18.19 & 12.65 & 18.30 \\
\hline 1.6 & 13.30 & 18.10 & 13.10 & 18.16 & 13.05 & 18.20 \\
\hline
\end{tabular}

water pressure during the shearing of the specimen was not measured.

\section{Results and Discussions}

\subsection{Compactio}

The compaction results for the clay reinforced with untreated/treated coir fibres are shown in Table 3. This table reveals that the optimum moisture content of the clay reinforced with treated and untreated coir fibres increases with the increases in the coir fibre content. The optimum moisture content of clay was $12.00 \%$, which increased to $12.60 \%, 12.30 \%$ and $12.28 \%$, respectively, when it was reinforced with $0.4 \%$ untreated, $0.4 \% \mathrm{NaOH}$ and $0.4 \% \mathrm{CCl}_{4}$ treated coir fibres. The optimum moisture content further increased to $13.30 \%, 13.10 \%$ and $13.05 \%$, respectively, when the clay was reinforced with $1.6 \%$ untreated, $1.6 \% \mathrm{NaOH}$ and $1.6 \% \mathrm{CCl}_{4}$ treated coir fibres. The increase in the optimum moisture content of a specimen of clay reinforced with untreated and treated coir fibres can be attributed to the water absorption tendency of the coir fibres. Table 3 further reveals that the optimum moisture content of the clay specimen reinforced with $\mathrm{NaOH}$ and $\mathrm{CCl}_{4}$ treated coir fibres is marginally smaller than clay reinforced with untreated coir fibres. This is attributed to the fact that the treatment with sodium hydroxide and carbon tetra chloride decreases the tendency of coir fibres to absorb water. The dry unit weight of the clay specimen reinforced with coir fibres decreases with increases in coir fibre content as evident from Table 3 The dry unit weight of the clay was $18.6 \mathrm{kN} / \mathrm{m}^{3}$ which decreased to $18.23 \mathrm{kN} / \mathrm{m}^{3}, 18.34 \mathrm{kN} / \mathrm{m}^{3}$ and $18.40 \mathrm{kN} / \mathrm{m}^{3}$ respectively, when it was reinforced with $0.4 \%$ untreated, $0.4 \% \mathrm{NaOH}$ treated and $0.4 \% \mathrm{CCl}_{4}$ treated coir fibres. The dry unit weight further decreased to $18.10 \mathrm{kN} / \mathrm{m}^{3}, 18.16 \mathrm{kN} / \mathrm{m}^{3}, 18.20 \mathrm{kN} / \mathrm{m}^{3}$ respectively, when the clay was reinforced with $1.6 \%$ untreated, $1.6 \% \mathrm{NaOH}$ treated and $1.6 \% \mathrm{CCl}_{4}$ treated coir fibres. Further, It should be noted from Table 3 that at a given fibre percentage, the dry unit weight of the clay reinforced with $\mathrm{CCl}_{4}$ treated fibre specimens is marginally higher than the respective values for the clay specimen reinforced with $\mathrm{NaOH}$ treated coir fibre. The reason for a slight increase in the unit weight of the clay reinforced with $\mathrm{CCl}_{4}$ treated coir fibre specimens can be attributed to better interaction of clay with fibre matrix as the surface cleaning of $\mathrm{CCl}_{4}$ treated fibres are better as compared to $\mathrm{NaOH}$ treated fibres. More details on the compaction behaviour are available from [13].

\subsection{Stress Ratio}

The stress strain behaviour of clay reinforced with different fibre percentages and at various confining pressures is indicated in Figs. 2, 3 and 4 respectively. The stress strain curve corresponding to unreinforced clay is also included in the respective 
plot for the sake of comparison. The results are presented in the form of stress ratio, which is a ratio of normalized stress to mean pressure, i.e. $q$ / $p$, where $q=\left(\sigma_{1}-\sigma_{3}\right)$ and $p=\left(\sigma_{1}+2 \sigma_{3}\right) / 3$. A study of Figs. 2-4 indicates that for a given confining pressure the stress ratio for the reinforced soil specimen was higher as compared to unreinforced clay at all fibre percentages. This observation was consistent at all confining pressure. A further study of these figures reveals that the stress-strain curve for soil reinforced with $\mathrm{NaOH}$ treated and $\mathrm{CCl}_{4}$ treated fibres plots above the curve corresponding to untreated fibres at any given confining pressure. This behaviour can be attributed to better interaction at soil-fibre interfaces due to treatment with $\mathrm{NaOH}$ and $\mathrm{CCl}_{4}$ which cleans the fibre surface and exposing them for an effective interaction with clay.

\subsection{Variations of Peak Deviator Stress Ratio with Fibre Content}

The variation of the peak deviator stress ratio (defined as the ratio of the peak deviator stress of reinforced specimen to the unreinforced one) with a fibre percentage of different confining pressure is indicated in Table 4 From Table 4 it can be seen that at a given confining pressure, the peak deviator stress of the clay reinforced with untreated and treated coir fibres increases with increases in fibre content. The addition of $0.4 \%$ untreated, $0.4 \% \mathrm{NaOH}$ treated and $0.4 \% \mathrm{CCl}_{4}$ treated coir fibres to the clay and at a confining pressure of $78.48 \mathrm{kPa}$, the peak deviator stress ratio were $1.49,1.58$, and 1.81 respectively. Further, at a confining pressure of $313.92 \mathrm{kPa}$, the peak deviator stress ratio increased to $2.36,2.502 .60$ respectively with the addition of $1.6 \%$ untreated, $1.6 \% \mathrm{NaOH}$ treated and $1.6 \% \mathrm{CCl}_{4}$ treated coir fibre to the clay. It should be noted that the peak deviator stress of the unreinforced clay at the confining pressure of $78.48 \mathrm{kPa}, 156.96 \mathrm{kPa}$ and $313.92 \mathrm{kPa}$ was $132.55 \mathrm{kPa}$, $139.73 \mathrm{kPa}$ and 163.27 respectively.

\subsection{Variations of Cohesion and Friction angle with Fibre Percentage}

As stated earlier, the pressure of pore water during the shearing of the specimen was not measured. Hence, only total stress shear strength parameters $\mathrm{c}$ and $\varphi$ were computed. The variations of cohesion and friction angle with fibre percentage are shown in Fig. 5 and 6 respectively. From these figures it can be seen that the addition of untreated and treated coir fibres to the clay leads to increase the cohesion and friction angle. Initially, the cohesion and friction angle of the clay was $56.72 \mathrm{kPa}$ and $3.58^{\circ}$ respectively; with the addition of $0.4 \%$ untreated, $0.4 \%$ $\mathrm{NaOH}$ treated and $0.4 \% \mathrm{CCl}_{4}$ treated fibres to the clay, the cohesion increased to $86.52,97.73$ and $103.14 \mathrm{kPa}$ respectively.

Similarly, the clay reinforced with $0.4 \%$ untreated, $0.4 \%$ $\mathrm{NaOH}$ treated and $0.4 \% \mathrm{CCl}_{4}$ treated fibres, showed the friction angles of $4.04^{\circ}, 5.53^{\circ}$ and $5.86^{\circ}$ respectively. The paar cohesionfriction angle further increased up to $138.63 \mathrm{kPa}$ and $6.21^{\circ}$, $140.55 \mathrm{kPa}$ and $7.2^{\circ}$, and $140.23 \mathrm{kPa}$ and $8.02^{\circ}$, respectively, as

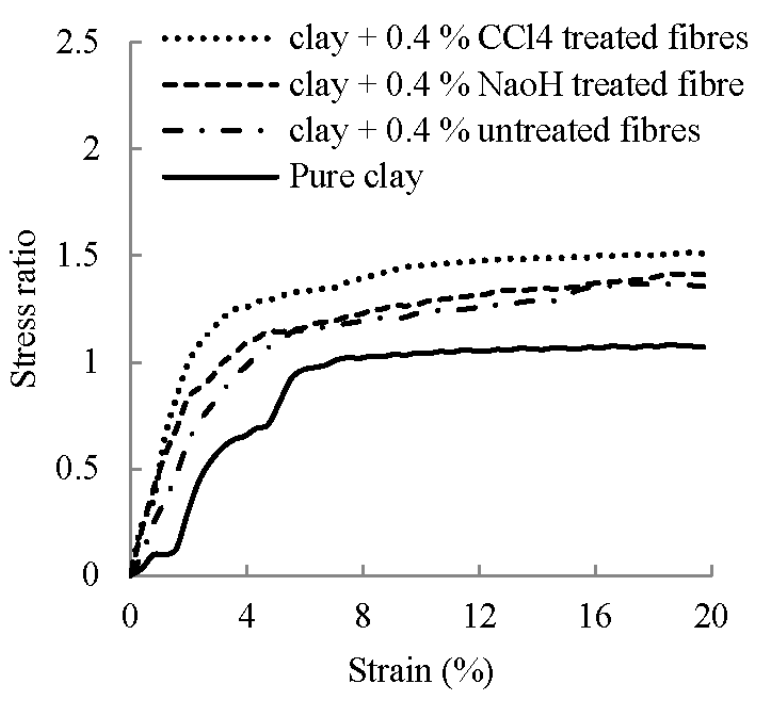

(a)

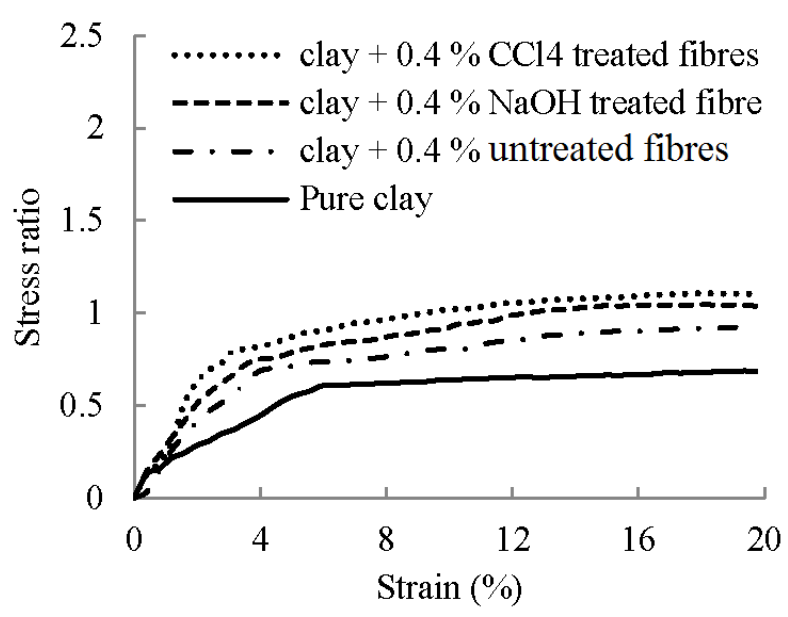

(b)

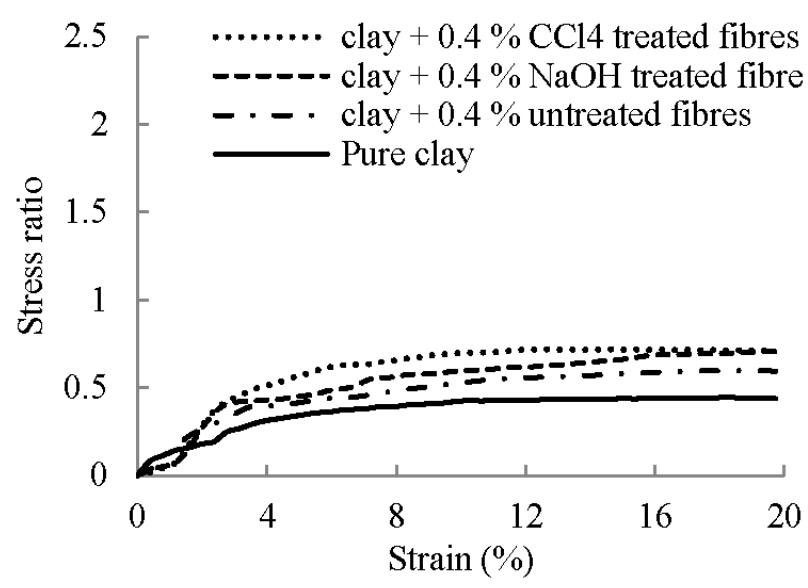

(c)

Fig. 2. Variations of stress ratio for clay $+0.4 \%$ fibres with confining pressure of (a) $78.48 \mathrm{kPa}$, (b) $156.96 \mathrm{kPa}$ and (c) $313.92 \mathrm{kPa}$. 
the content of untreated, $\mathrm{NaOH}$ treated, $\mathrm{CCl}_{4}$ treated coir fibre in clay was increased to $1.6 \%$. Addition of $\mathrm{CCl}_{4}$ treated coir fibres to the clay resulted more improvement in cohesion and friction angle in comparison to $\mathrm{NaOH}$ treated coir fibres. This is attributed to the better cleaning of fibres with $\mathrm{CCl}_{4}$ in comparison to $\mathrm{NaOH}$ leading to a better interaction between the clay and coir fibres.

\subsection{Hyperbolic Stress-Strain Relationship}

In order to predict the stress-strain response of soil a two parameter dependent [15] hyperbolic model was employed. This model is defined as

$$
\frac{\varepsilon}{\sigma_{1}-\sigma_{3}}=a+b . \varepsilon
$$

where,

$$
\begin{aligned}
& \varepsilon \quad \text { strain at failure } \\
& \sigma_{1}-\sigma_{3} \text { deviator stress at failure } \\
& a \text { and } b \text { are material constants }
\end{aligned}
$$

The inverse of parameter " $a$ " and " $b$ " yields the initial elastic modulus and ultimate strength respectively. Many researchers have found the validity of this relationship for various kinds of soils and rocks under various test conditions [16]. In order to assess its validity for clay reinforced with untreated/treated coir fibres, the present results have been analysed. These parameters are obtained by fitting a linear line on a plot of $\varepsilon / \sigma_{1}-\sigma_{3}$ vs $\varepsilon$ as obtained from the relevant experimental results. Typical linear plot of $\varepsilon / \sigma_{1}-\sigma_{3}$ vs $\varepsilon$ for the clay and clay reinforced with $1.6 \%$ untreated, $\mathrm{NaOH}$ and $\mathrm{CCl}_{4}$ treated coir fibres is shown in Fig. 7. The back predicted stress-strain curves along with the respective experimental results for few selected values of confining pressure and fibre content are indicated in Figs. 814 From these figures it can be observed that the predicted stress-strain curves are in good agreement with the experimental observations for both unreinforced clay and clay reinforced with untreated/treated fibres.

Further, [17] reported that coir Geotextiles retained 20\% of their original tensile strength after one year when placed in incubator in high fertile soil. It was further reported that coir remained undamage after 167 days into shower room. The loss in strength of a coir rope after placing for 10 months in pulverized ash was $20 \%$ [18]. Coir degrades at a faster rate in sand having high organic content followed by clay with high organic content and finally saturated soft clay, where the degradation was the least [19].

It was further reported by [19] that the overall life of coir is more than two/three years and brown coir degrades (about 20\% in 7 months) at a faster rate than white coir (about $10 \%$ in 7 months). Thus the untreated/treated coir fibres in clay matrix have adequate durability and can be used in short term stability related problems.

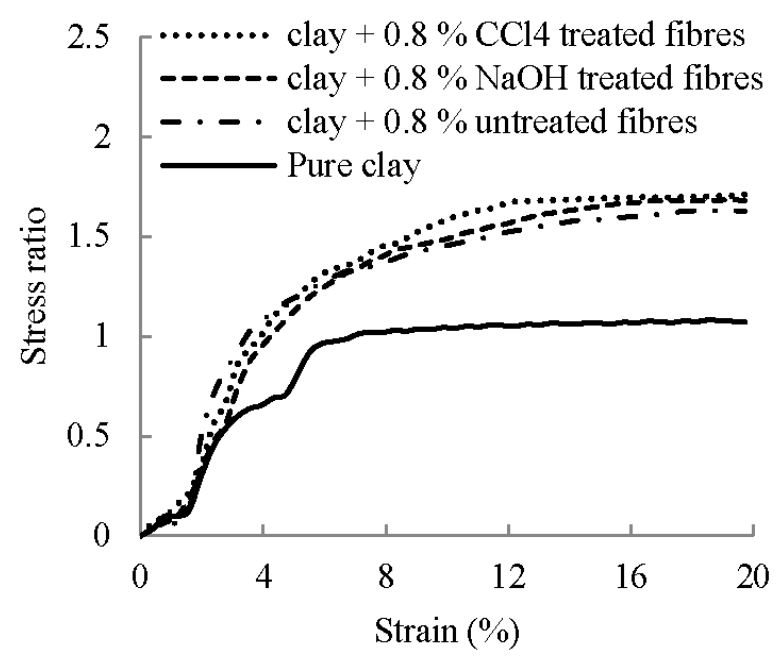

(a)

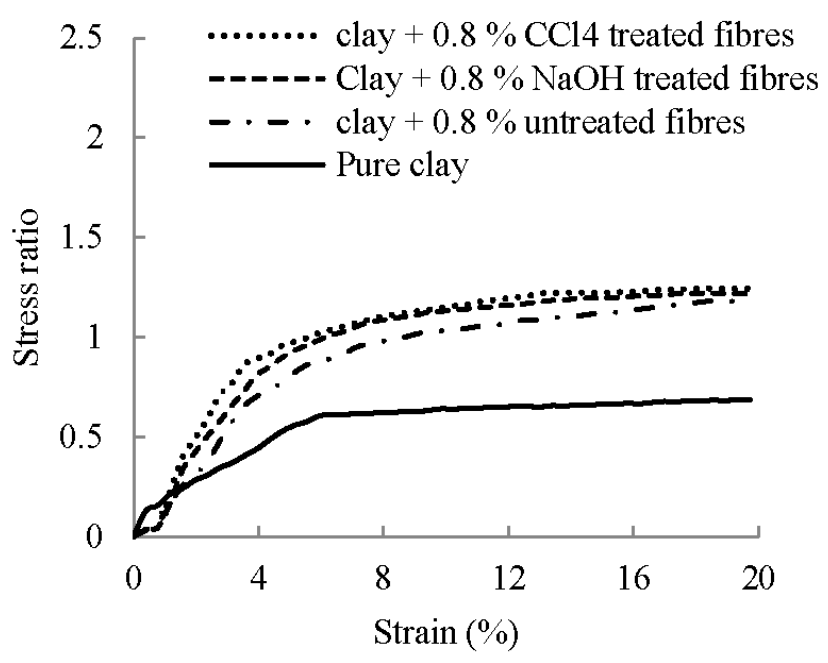

(b)

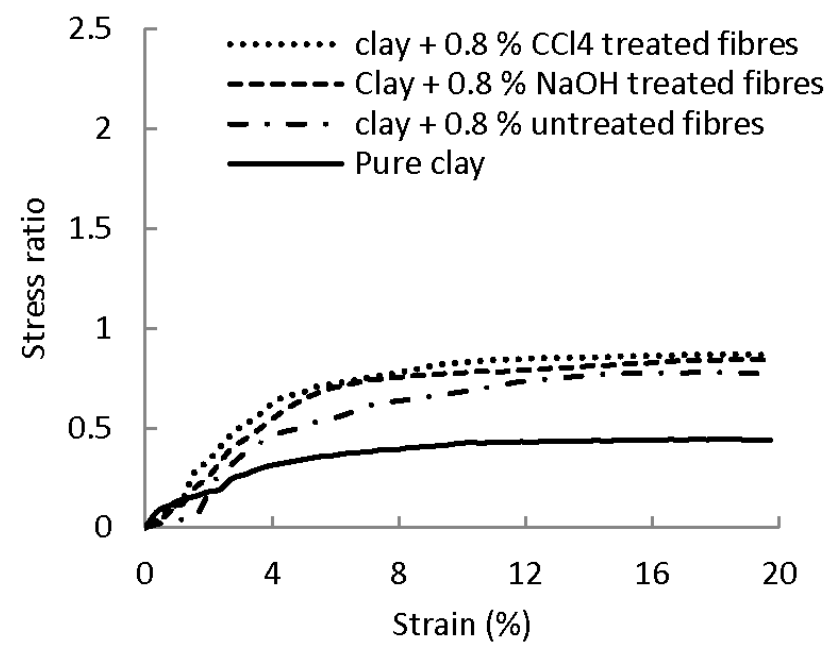

(c)

Fig. 3. Variations of stress ratio for clay $+0.8 \%$ fibres with confining pressure of (a) $78.48 \mathrm{kPa}$, (b) $156.96 \mathrm{kPa}$ and (c) $313.92 \mathrm{kPa}$. 
Tab. 4. Variations of peak deviator stress with fibre percentage and confining pressure

\begin{tabular}{|c|c|c|c|c|}
\hline \multirow{2}{*}{ Type of treatment } & \multirow{2}{*}{ Confining pressures $(\mathrm{kPa})$} & \multicolumn{3}{|c|}{ Peak deviator stress ratio } \\
\hline & & $0.4 \%$ fibre & $0.8 \%$ fibre & $1.6 \%$ fibre \\
\hline \multirow{3}{*}{ Untreated fibres } & 78.48 & 1.49 & 2.11 & 2.47 \\
\hline & 156.96 & 1.50 & 2.19 & 2.50 \\
\hline & 313.92 & 1.43 & 2.02 & 2.36 \\
\hline \multirow{3}{*}{$\mathrm{NaOH}$ treated fibres } & 78.48 & 1.58 & 2.27 & 2.57 \\
\hline & 156.96 & 1.80 & 2.31 & 2.61 \\
\hline & 313.92 & 1.67 & 2.26 & 2.50 \\
\hline \multirow{3}{*}{$\mathrm{CCl}_{4}$ treated fibres } & 78.48 & 1.81 & 2.35 & 2.62 \\
\hline & 156.96 & 1.97 & 2.39 & 2.68 \\
\hline & 313.92 & 1.81 & 2.35 & 2.60 \\
\hline
\end{tabular}

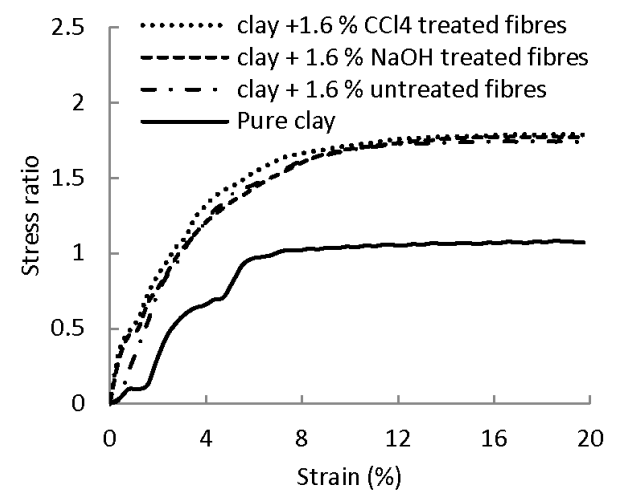

(a)

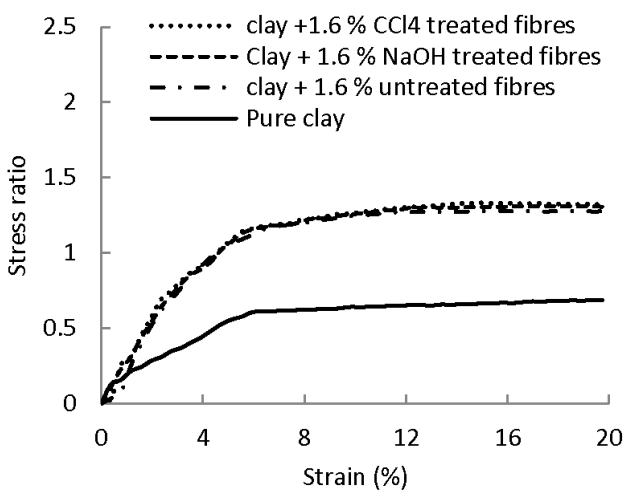

(b)

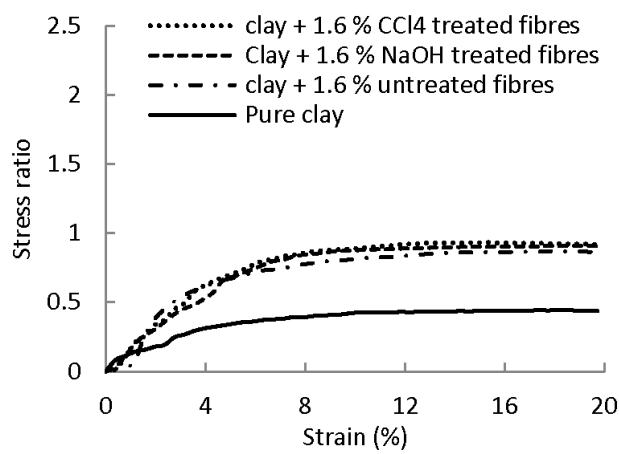

(c)

Fig. 4. Variations of stress ratio for clay $+1.6 \%$ fibres with confining pressure of (a) $78.48 \mathrm{kPa}$, (b) $156.96 \mathrm{kPa}$ and (c) $313.92 \mathrm{kPa}$.

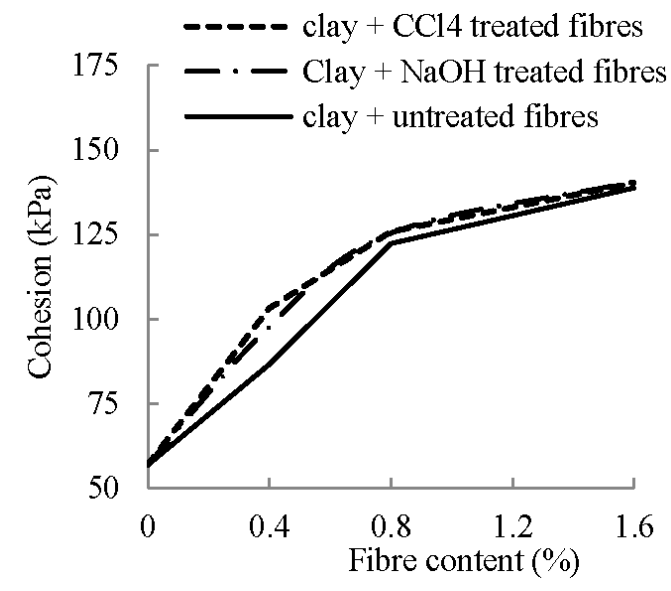

Fig. 5. Variations of cohesion with fibre content

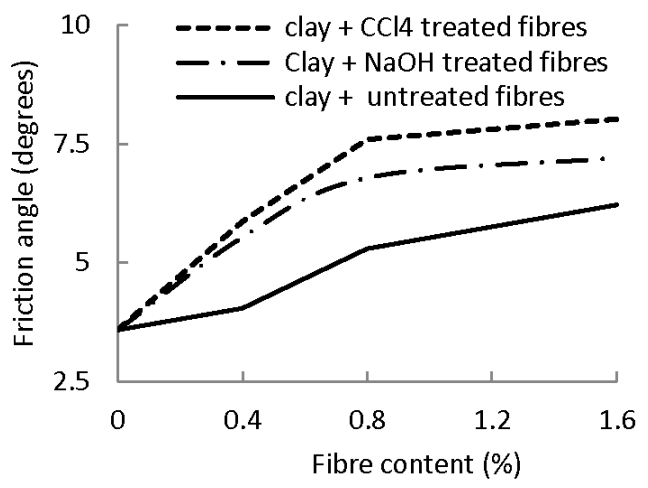

Fig. 6. Variations of friction angle with fibre content

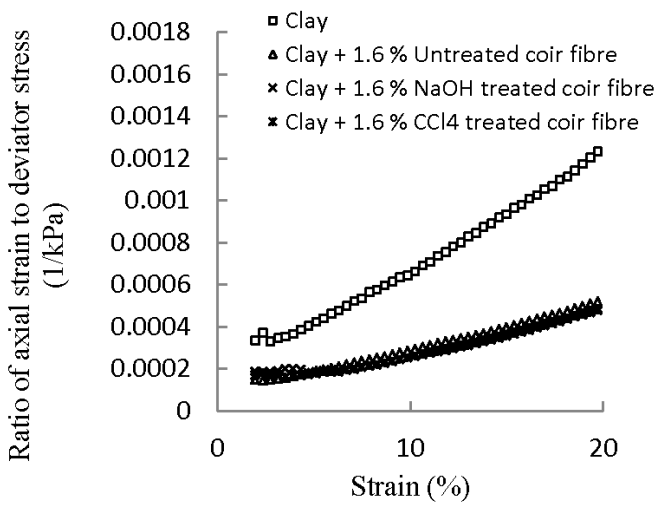

Fig. 7. Plot between ratio of axial strain to deviator stress versus percentage axial strain for clay reinforced with $1.6 \%$ untreated, $\mathrm{NaOH}$ and $\mathrm{CCl}_{4}$ treated coir fibres 


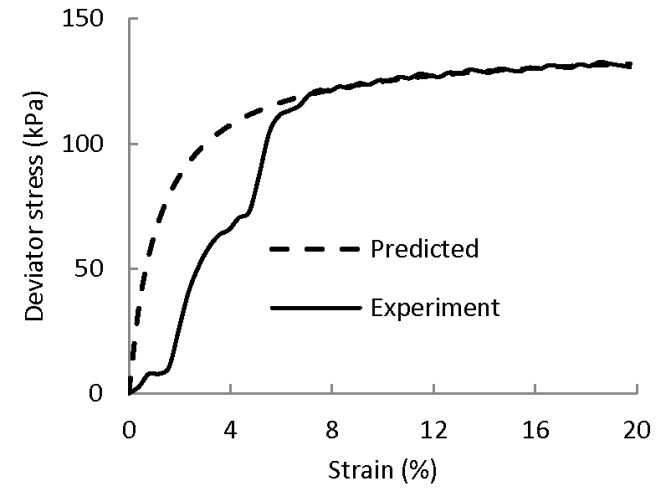

(a)

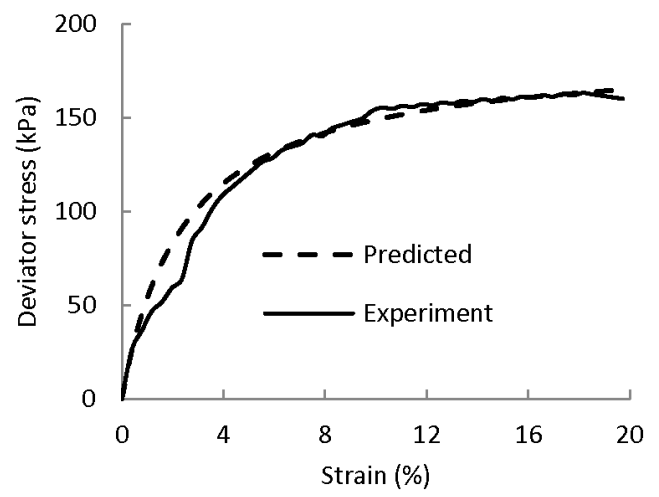

(b)

Fig. 8. Predicted stress-strain curves from hyperbolic model for pure clay with confining pressure of (a) $78.48 \mathrm{kPa}$ and (b) $313.92 \mathrm{kPa}$.

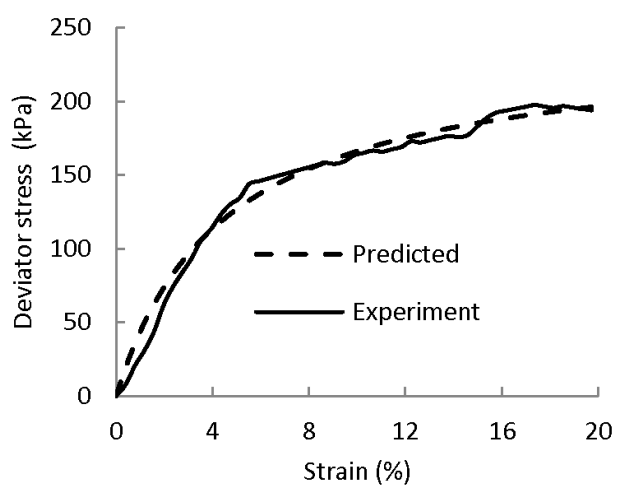

(a)

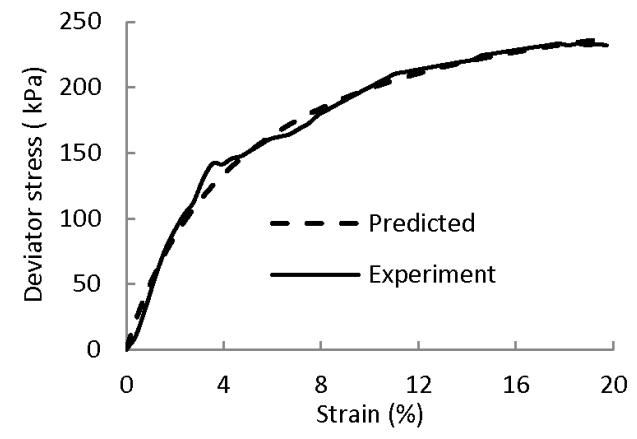

(b)

Fig. 9. Predicted stress-strain curves from hyperbolic model for clay reinforced with $0.4 \%$ untreated fibres with confining pressure of (a) $78.48 \mathrm{kPa}$ and (b) $313.92 \mathrm{kPa}$.

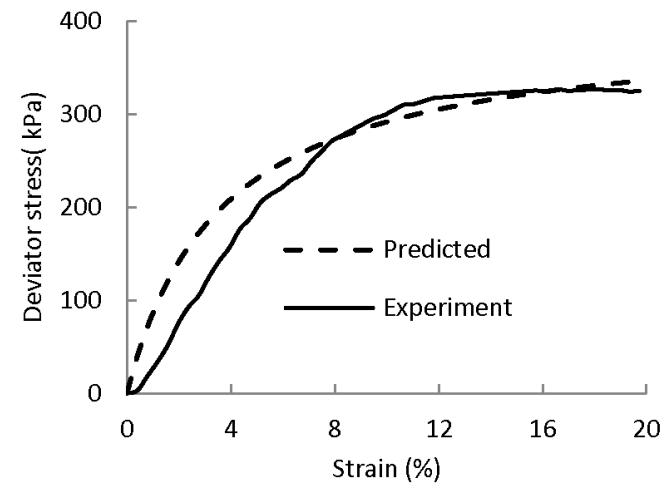

(a)

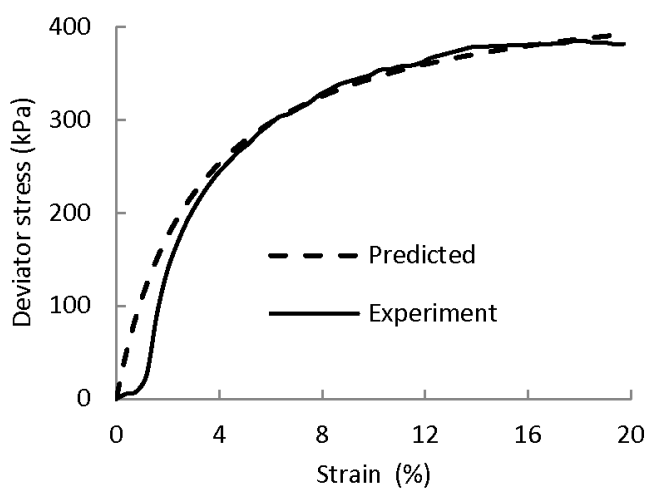

(b)

Fig. 10. Predicted stress-strain curves from hyperbolic model for clay reinforced with $1.6 \%$ untreated fibres with confining pressure of (a) $78.48 \mathrm{kPa}$ and (b) $313.92 \mathrm{kPa}$.

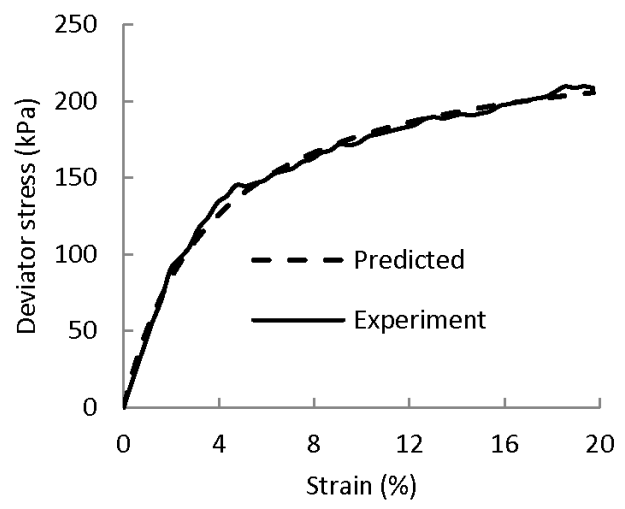

(a)

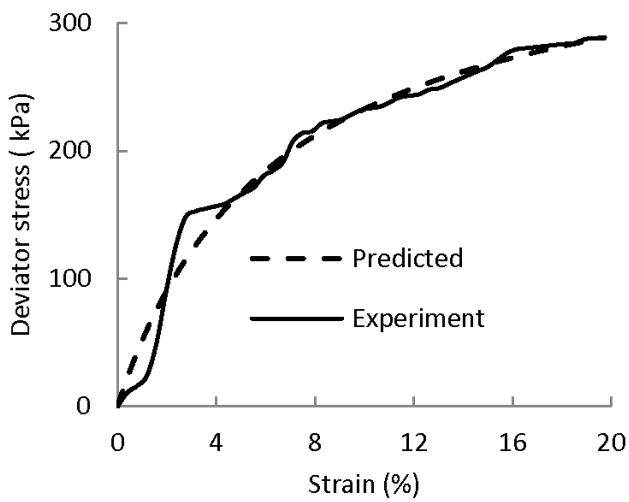

(b)

Fig. 11. Predicted stress-strain curves from hyperbolic model for clay reinforced with $0.4 \% \mathrm{NaOH}$ treated fibres with confining pressure of (a) $78.48 \mathrm{kPa}$ and (b) $313.92 \mathrm{kPa}$. 


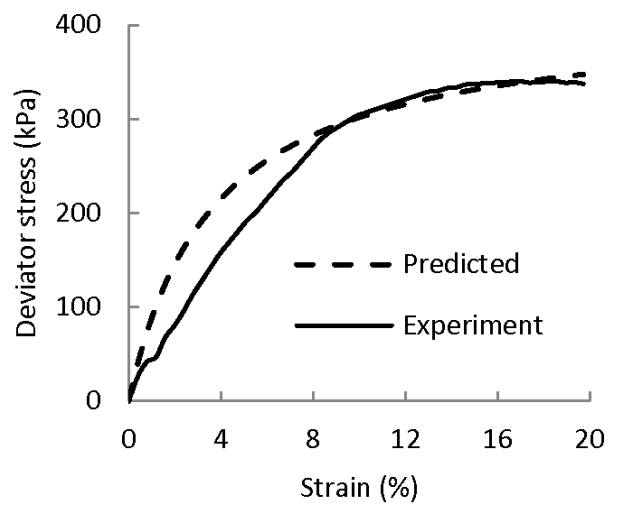

(a)

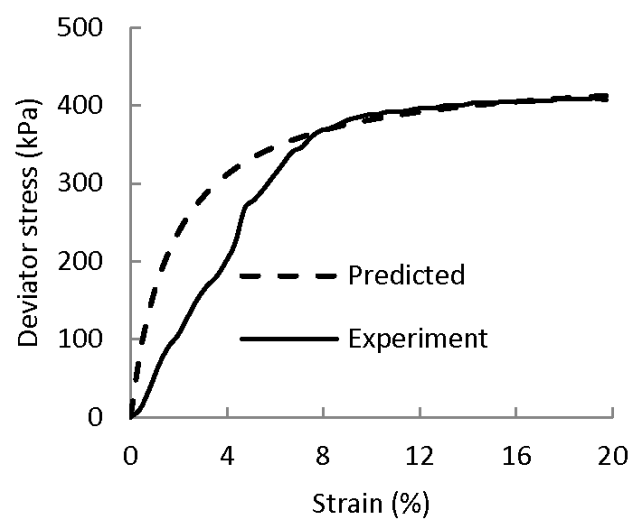

(b)

Fig. 12. Predicted stress-strain curves from hyperbolic model for clay reinforced with $1.6 \% \mathrm{NaOH}$ treated fibres with confining pressure of (a) $78.48 \mathrm{kPa}$ and (b) $313.92 \mathrm{kPa}$.

\section{Conclusions}

This study examined the effect of untreated/treated coir fibres on the shear strength behaviour of the clay reinforced with $0.4 \%$, $0.8 \%$ and $1.6 \%$ fibre content. The results have shown that the shear strength behaviour of the clay reinforced with coir fibres can be improved by treating with sodium hydroxide and carbon tetrachloride. The study brings forth the following conclusions:

1 The peak deviator stress of the clay reinforced with coir fibres can be significantly improved with the treatment with $\mathrm{NaOH}$ and $\mathrm{CCl}_{4}$.

2 The peak deviator stress, cohesion and friction angle increase with the coir fibre content.

3 The improvement in peak deviator stress, cohesion and friction angle was highest with the addition of $\mathrm{CCl}_{4}$ treated coir fibres in comparison to $\mathrm{NaOH}$ treated coir fibres in clay.

4 The hyperbolic model can be used for predicting the stress strain response of unreinforced and reinforced clay with the appropriate selection of the model parameters.

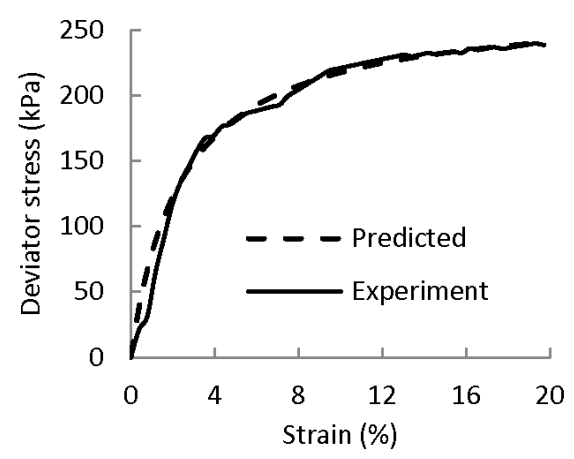

(a)

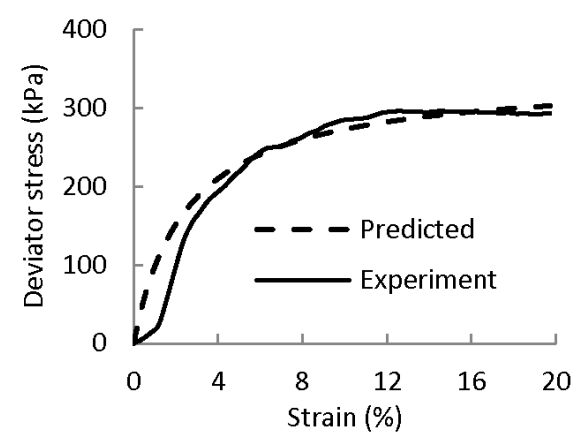

(b)

Fig. 13. Predicted stress-strain curves from hyperbolic model for clay reinforced with $0.4 \% \mathrm{CCl}_{4}$ treated fibres with confining pressure of (a) $78.48 \mathrm{kPa}$ and (b) $313.92 \mathrm{kPa}$.

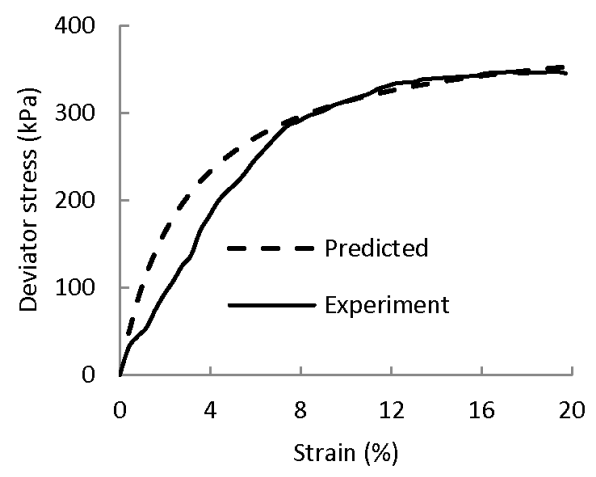

(a)

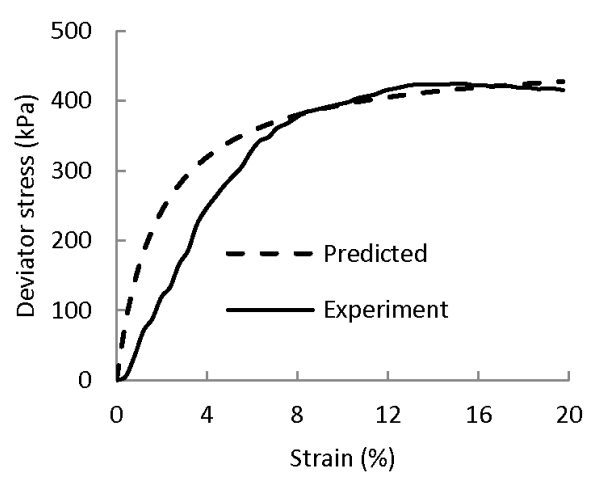

(b)

Fig. 14. Predicted stress-strain curves from hyperbolic model for clay reinforced with $1.6 \% \mathrm{CCl}_{4}$ treated fibres with confining pressure of (a) $78.48 \mathrm{kPa}$ and (b) $313.92 \mathrm{kPa}$. 


\section{References}

1 Rao GV, Dutta RK, Damarashetty U, Strength characteristics of sand reinforced with coir fibres and coir geotextiles, Electronic Journal of Geotechnical Engineering, 10(G), (2005), http://www.ejge.com/2005/Ppr0602/Ppr0602.htm.

2 Rao GV, Balan K, Coir geotextiles - emerging trends, Kerala State Coir Corporation Limited, Alappuzha; Kerala, India, 2000.

3 Prasad SV, Pavithran C, Rohatgi PK, Alkali treatment of coir fibres for coir-polyester composites, Journal of Materials Science, 18(5), (1983), 14431454, DOI 10.1007/BF01111964

4 Banerjee PK, Chattopadhyay R, Guha A, Investigations into homogeneity of coir fibres, Indian Journal of Fibre and Textile Research, 27, (2002), 111116.

5 Babu GLS, Vasudevan AK, Strength and stiffness response of coir fibrereinforced tropical soil, Journal of Materials in Civil Engineering, 20(9), (2008), 571-577, DOI 10.1061/(ASCE)0899-1561(2008)20:9(571)

6 Mwasha PA, Coir fibre: a sustainable engineering material for the Caribbean environment, The College of the Bahamas Research Journal, 15, (2009), 36-44.

7 Babu GLS, Choksey S, Model for analysis of fibre-reinforced clayey soil, Geomechanics and Geoengineering: An International Journal, 5(4), (2010), 277-285, DOI 10.1080/17486021003706804

8 Ramesh HN, Krishna MKV, Mamatha HV, Compaction and behaviour of lime coir fibre treated black cotton soil, Geomechanics and Engineering-An International Journal, 2(1), (2010), 19-28, DOI 10.12989/gae.2010.2.1.019

9 Dasaka SM, Sumesh KS, Effect of coir fibre on the stress-strain behavior of a reconstituted fine-grained soil, Journal of Natural Fibres, 8(3), (2011), 189-204, DOI 10.1080/15440478.2011.601597

10 Dutta RK, Khatri VN, Gayathri V, Effect of addition of treated coir fibres on the compression behaviour of clay, Jordan Journal of Civil Engineering, 6(4), (2012), 476-488.

11 IS 2720-Part-VII (Reaffirmed 1997). Determination of water content-dry density relation using light compaction. Indian Standard methods of test for soils, Bureau of Indian Standards; New Delhi, India, 1980.

12 Dixit S, Verma $\mathbf{P}$, The effect of surface modification on the water absorption behavior of coir fibres, Advances in Applied Science Research, 3(3), (2012), 1463-1465.

13 Dutta RK, Khatri VN, Gayathri V, Effect of treated coir fibres on the compaction and CBR behaviour of clay, International Journal of Geotechnics and Environment, 5(1), (2013), 19-33.

14 IS 2720 : Part 12 : Determination of shear strength parameters of soil from consolidated undrained triaxial compression test with measurement of pore water pressure, Bureau of Indian Standards, New Delhi, 1981.

15 Kondner RL, Zelasko JS, A hyperbolic stress strain formulations for sands, In: Proc. 2nd Pan. Am. Conf., Soil Mechanics and Foundation Engineering 1963; ASCE, 1, pp. 289-324.

16 Sridharan A, Rao NS, Hyperbolic representation of strength, pore pressures and volume changes with axial strain in triaxial test, In: Symp. on Strength and Deformation Behaviour of Soils 1972; Bangalore, India, 1, pp. 33-42.

17 Schurholz H, Use of woven coir geotextiles in Europe, Coir News, 35(2), (1991), 18-25.

18 Sarsby RW, Ali M, DeAluis R, Khoffot JH, Medongall JM, Low cost soil reinforcement for developing countries, In: Proc. Int. Conf. on Non-wovens 1992; The Textile Institute, North India Section, pp. 297-310.

19 Balan K, Studies on engineering behavior and uses of geotextiles with natural fibers, PhD thesis, Indian Institute of Technology; Delhi, India, 1995. 